\title{
STATUS KEBERLANJUTAN PERIKANAN PURSE SEINE NELAYAN ANDON DAN NELAYAN LOKAL DI SELAT SUNDA
}

\author{
Agus Heri Purnomo, Tjahjo Tri Hartono dan Zahri Nasution")
}

\begin{abstract}
ABSTRAK
Penelitian ini dilakukan pada bulan Desember 2003 hingga Januari 2004, dengan tujuan untuk melakukan diagnosa keberlanjutan perikanan nelayan andon dan nelayan lokal di Selat Sunda. Untuk itu, pendekatan utama yang diterapkan adalah Rapfish (Rapid Appraisal for Fisheries), suatu teknik yang memungkinkan penilaian secara cepat kondisi perikanan ditinjau dari berbagai aspek atau dimensi. Komponen-komponen atau atribut dari masing-masing dimensi dianalisis melalui pembuatan skala multi dimensi (Multi Dimensional Scaling). Dimensi-dimensi yang ditinjau mencakup dimensi ekonomi, ekologi, etika, sosial, teknologi, dan kebaharian. Hasil penelitian menunjukkan bahwa kinerja dari kedua perikanan yang dianalisis berklasifikasi 'sedang', sehingga prospek keberlanjutannya dapat dipandang masih cukup baik. Namun demikian, meningkatnya intensitas dan kualitas konflik antar kelompok nelayan andon dan nelayan lokal masih perlu diwaspadai karena dapat menjurus pada turunnya kinerja perikanan wilayah tersebut sekaligus resiko ketidak-berlanjutan yang lebih besar. Penelitian ini juga mengindikasikan perlunya penyempurnaan kebijakan yang tersangkut dengan pengembangan teknologi penangkapan ramah lingkungan, skema dan pelaksanaan kredit pembiayaan kegiatan penangkapan dan mata pencaharian alternatif untuk nelayan lokal serta penanganan illegal fishing.
\end{abstract}

ABSTRACT: The sustainability status of andon and local purse seine fisheries in the Sunda Strait. By : Agus Heri Purnomo, Tjahjo Tri Hartono and Zahri Nasution

The research aimed to diagnose the sustainability status of capture fisheries done by andon fishers and local fishers in the Sunda Strait, Indonesia, was carried out in December 2003 till January 2004. The approach follows the Rapfish (Rapid Appraisal for Fisheries) method, a technique which is enable a rapid process of portraying fisheries condition based on assessment carried out from different angles or dimensions. Components or attributes composing each dimension are analyzed through Multi Dimensional Scaling. These dimensions include ecological, economic, ethical, social, technological, and maritime affair dimensions. This research shows that Sunda Strait Fisheries' sustainability status can be classified as 'moderate', meaning that the sustainability prospect can be expected to 'not too bad'. This research also indicates that there is an urgent need of improving existing policies on development of environmental friendly of capture technology, scheme and implementation of fund credits of capture fishing activities and other livelihoods for local fishers and illegal fishing handling.

KEYWORDS: $\quad$ rapfish, Sunda Strait, sustainability, fisheries, andon fishers, local fishers

\section{PENDAHULUAN}

Selat Sunda merupakan kawasan perairan dengan potensi perikanan tangkap yang cukup besar dan karenanya dianggap sebagai aset penting bagi Propinsi Lampung dan Propinsi Banten yang membatasinya. Berbagai spesies ekonomis, baik dari kelompok pelagis maupun demersal, terdapat di perairan ini dalam kawasan tersebut. Namun demikian, potensi perikanan tangkap di perairan Selat Sunda tidak hanya dimanfaatkan oleh nelayan lokal, tetapi pada musim-musim tertentu, wilayah perairan ini juga dimanfaatkan oleh nelayan andon, yaitu nelayan purse seine pendatang dari luar daerah atau propinsi. Bahkan pada perikanan tertentu, nelayan purse seine andon menunjukkan dominasinya, baik dalam hal besarnya armada dan ukuran kapal penangkap yang digunakan, tingkat produksi, maupun skala usaha yang diterapkan.

Di satu sisi, keberadaan nelayan andon dengan kelebihan teknologi penangkapan yang dimilikinya dibandingkan nelayan lokal dapat dipandang sebagai hal yang positif karena dapat menghindarkan underexploitation. Di sisi lain, keberadaan nelayan andon merupakan potensi masalah yang cukup signifikan bagi perikanan di Selat Sunda. Hal-hal yang berpotensi menjadi masalah adalah yang terkait dengan ketimpangan kesejahteraan dengan nelayan lokal,

\footnotetext{
"Peneliti pada Pusat Riset Pengolahan Produk dan Sosial Ekonomi Kelautan dan Perikanan
} 
besarnya kapasitas alat tangkap nelayan andon yang dapat menjadi penyebab terjadinya over-exploitation serta registrasi eksploitasi. Di samping itu, otonomi daerah yang diterapkan sejak beberapa tahun lalu telah menambah kompleksitas permasalahan. Sebagai contoh, dengan semangat otonomi daerah, konflik transparan terjadi antara nelayan andon dengan nelayan lokal, baik di Lampung maupun di Banten. Meskipun dalam konteks yang lebih sempit kejadian tersebut dapat berdampak positif terhadap kelompok nelayan lokal, dalam konteks yang lebih besar, dengan asumsi bahwa eksploitasi masih berada di bawah tingkat optimalnya, kejadian tersebut dapat berakibat pada penurunan nilai total ekonomi yang tergali dari perikanan di Selat Sunda.

Menimbang besarnya potensi dan kompleksitas perikanan di Selat Sunda yang muncul akibat beroperasinya nelayan andon di perairan tersebut, maka penelitian ini bertujuan melihat kinerja perikanan andon dibandingkan dengan lokal pada berbagai dimensi yang dipandang perlu untuk dilaksanakan. Diharapkan, hasil dari penelitian ini dapat memberikan arah dalam penentuan aspek yang perlu mendapatkan perhatian lebih besar di masa depan.

\section{METODE}

\section{Kerangka Pendekatan}

Pendekatan yang digunakan dalam penelitian ini adalah Rapfish (Rapid Appraisal for Fisheries), yang diaplikasikan untuk mengukur status kelestarian sumberdaya perikanan, dalam hal ini di perairan Selat Sunda). Pendekatan ini dikembangkan berdasarkan kerangka atau konsep pembangunan berkelanjutan yang merujuk pada pembangunan perikanan berkelanjutan sebagaimana termaksud dalam Code of Conduct for Responsible Fisheries (Pitcher \& Preikshot, 2001). Teknik ini memungkinkan dilakukannya diagnosa terhadap kondisi suatu perikanan berdasarkan hasil pengukuran beberapa indikator, yang dalam peristilahan Rapfish dikenal sebagai dimensi. Dalam analisis ini, dimensi yang dilihat adalah Dimensi Ekologis, Ekonomi, Sosial, Teknologi, Etika dan Dimensi Kebaharian. Pengukuran dimensi yang disebut terakhir (Dimensi Kebaharian) belum pernah dilakukan di negara lain. Namun demikian, berdasarkan hasil beberapa aplikasi Rapfish di berbagai kasus yang dilakukan oleh peneliti Pusat Riset Pengolahan Produk dan Sosial Ekonomi Kelautan dan Perikanan, dimensi ini sangat penting karena merupakan akar dari berbagai dimensi lain yang selama ini diterapkan. Penerapan Dimensi Kebaharian juga dimaksudkan untuk mengakomodasikan aspek khas Indonesia sebagaimana tertuang dalam statemen misi Departemen Kelautan dan Perikanan

Masing-masing dimensi terdiri dari berbagai atribut penjelas, yang berfungsi menggambarkan kondisi/ dimensi perikanan yang dianalisis. Sebagai contoh, Dimensi Ekonomi terdiri dari 10 atribut (di antaranya profitabilitas, sumbangan terhadap GDP) dan Dimensi Ekologi terdiri dari 9 atribut (di antaranya status eksploitasi, ukuran rata-rata ikan yang ditangkap, jangkauan ruaya ikan, dan sebagainya). Analisis tersebut didasarkan pada skoring yang dilakukan terhadap enam jenis perikanan tangkap berdasarkan masing-masing atribut pada dua propinsi (Propinsi Lampung dan Propinsi Banten).

Berdasar data skoring tersebut kemudian dilakukan analisis multidimensi dengan menghitung jarak antar masing-masing atribut. Perhitungan jarak tersebut dilakukan dengan Minkowski Metric (Nijkamp, 1979 dalam Nijkamp, 1980) yang dinyatakan dalam Kuadrat Jarak Euclidian. Untuk melakukan pemetaan dalam satu dimensi horizontal, dilakukan rotasi ordinasi. Hal ini dimaksudkan untuk memplot titik posisi tersebut dalam satu jarak dua dimensi dalam skala buruk "bad" (0\%) dan baik "good" (100\%) dalam skor kelestarian sumberdaya perikanan. Hasilnya kemudian dikaji lebih lanjut dengan analisis leverage yang menghasilkan faktor-faktor yang berpengaruh dalam menentukan nilai skala yang didapat dari perikanan yang dianalisis.

\section{Lokasi dan Waktu Penelitian}

Lokasi penelitian adalah Lempasing, Kota Bandar Lampung, Propinsi Lampung dan Panimbang, Kabupaten Pandeglang, Propinsi Banten. Lokasilokasi dipilih karena merupakan pusat-pusat pendaratan nelayan andon dan nelayan lokal di Propinsi Banten dan Propinsi Lampung yang beroperasi di sekitar perairan Selat Sunda. Penelitian ini dilakukan bulan Desember 2003 - Januari 2004.

\section{Metoda Pengumpulan Data}

Metode penelitian yang digunakan adalah studi kasus (case study). Studi kasus adalah suatu strategi penelitian multi-metode, lazimnya memadukan teknik pengamatan, wawancara dan analisis dokumen (Daniel, 2002). Kasus yang dihadapi adalah keberlanjutan usaha perikanan tangkap di Selat Sunda.

Sesuai dengan definisinya, Rapfish diterapkan untuk melaksanakan pengukuran secara cepat. Sehubungan dengan itu, data-data yang digunakan dalam penelitian ini sedapat mungkin diperoleh dengan cara atau proses yang tidak memerlukan waktu terlalu banyak. Pengumpulan laporan-laporan terkait atau 
publikasi ilmiah yang ada, konsultasi ahli, atau bahkan pengembangan intuisi peneliti dilakukan untuk memperoleh data yang sedapat mungkin akurat. Dalam hal ini, satu jenis data yang sama sering perlu diperoleh melalui pengecekan ulang berdasarkan informasi yang diperoleh dari berbagai sumber. Verifikasi lapang, yang dimaksudkan untuk melakukan observasi langsung dan melakukan wawancara konfirmasi, termasuk dengan nelayan, pengolah ikan atau informan kunci lainnya, dilakukan untuk lebih meningkatkan akurasi data. Wawancara ini dilakukan dengan bantuan kuesioner, dengan tujuan untuk memandu enumerator dalam menggali informasi, sehingga langsung terkait dengan atribut Rapfish.

\section{Metoda Analisis}

Data yang diperoleh dengan pendekatan di atas kemudian diolah dan dianalisis melalui tahapantahapan berikut: (1) Tabulasi: Data yang dikumpulkan dikaji ulang beberapa kali untuk mendapatkan angka atau jawaban final terhadap pertanyaan-pertanyaan menyangkut atribut Rapfish. Data ini kemudian ditabulasikan; hasil tabulasi ini merupakan bahan dasar bagi tahapan entri data ke program Rapfish; (2) Entri ke program Rapfish: Data-data hasil tabulasi dikonversikan ke angka-angka skor (Lampiran 1) yang diberikan menurut standar Rapfish; (3) Interpretasi hasil: Dalam hal ini, pada setiap perikanan diamati dimensi-dimensi yang berkinerja baik, sedang, dan buruk. Untuk masing-masing dimensi tersebut, juga dilihat atribut-atribut yang sensitif, yaitu atribut yang paling berpengaruh terhadap tingkatan baik buruknya kinerja untuk masing-masing dimensi (disebut dengan analisis leverage); dan (4) Diskusi dan re-interpretasi hasil: Dalam tahap ini, hasil interpretasi awal dari rapfish dikaji ulang berdasarkan catatan lapang atau data-data relevan lain untuk mempertajam dan lebih meningkatkan akurasi data hasil pengolahan program Rapfish.

\section{HASIL DAN BAHASAN}

\section{Status Perikanan Purse Seine Nelayan Andon dan Nelayan Lokal di Selat Sunda}

Hasil analisis ordinansi Rapfish terhadap perikanan nelayan andon dan nelayan lokal yang beroperasi di Selat Sunda disajikan pada Tabel 1.

Melalui diagram radar pada Gambar 1, yang dibuat berdasarkan nilai-nilai pada Tabel 1, maka tampak adanya persamaan pola antara nelayan andon dengan nelayan lokal. Namun demikian, seberapa besar peran masing-masing dimensi akan memberikan arah pada pemilihan opsi yang dapat dipertimbangkan untuk diterapkan dengan harapan dapat meningkatkan kinerja secara keseluruhan. Berikut ini merupakan tinjauan lebih lanjut terkait dengan signifikansi dari peran masing-masing atribut, yang dikaitkan dengan permasalahan yang spesifik di masing-masing perikanan.

Tabel 1. Skala kinerja status perikanan purse seine nelayan andon dan lokal di Selat Sunda, 2003

Table 1. Performance scale of various status dimensions of andon and local purse seine fisheries in Sunda Strait, 2003

\begin{tabular}{|c|c|c|c|c|c|c|}
\hline Alat/Gears & $\begin{array}{l}\text { Ekologi/ } \\
\text { Ecology }\end{array}$ & $\begin{array}{l}\text { Ekonomi/ } \\
\text { Economic }\end{array}$ & $\begin{array}{l}\text { Sosiall } \\
\text { Social }\end{array}$ & $\begin{array}{l}\text { Teknologi/ } \\
\text { Technology }\end{array}$ & $\begin{array}{l}\text { Etika/ } \\
\text { Ethics }\end{array}$ & $\begin{array}{c}\text { Kebaharian/ } \\
\text { Maritime Affairs }\end{array}$ \\
\hline $\begin{array}{l}\text { Purse seine andon, } \\
\text { Panimbang/Andon purse seine } \\
\text { fisheries, Panimbang }\end{array}$ & 65 & 46 & 57 & 39 & 49 & 59 \\
\hline $\begin{array}{l}\text { Mini purse seine lokal, } \\
\text { Lempasing/Local mini purse } \\
\text { seine fisheries, Lempasing }\end{array}$ & 60 & 46 & $56^{*}$ & $44^{\star}$ & 47 & 57 \\
\hline $\begin{array}{l}\text { Purse seine andon, } \\
\text { Lempasing/Andon purse seine } \\
\text { fisheries, Lempasing }\end{array}$ & 59 & 46 & 51 & 40 & 47 & 57 \\
\hline
\end{tabular}

Keterangan/Notes: Tanda bintang $\left(^{*}\right)$ menunjukkan kondisi nelayan lokal yang lebih baik dibandingkan dengan nelayan andon/Value which is marked by star $\left({ }^{*}\right)$, shows a better condition of local fisheries compared to andon

Sumber/Sources: $\quad$ Olahan data hasil Rapfish Analysis, 2004/Data processed by Rapfish Analysis, 2004 


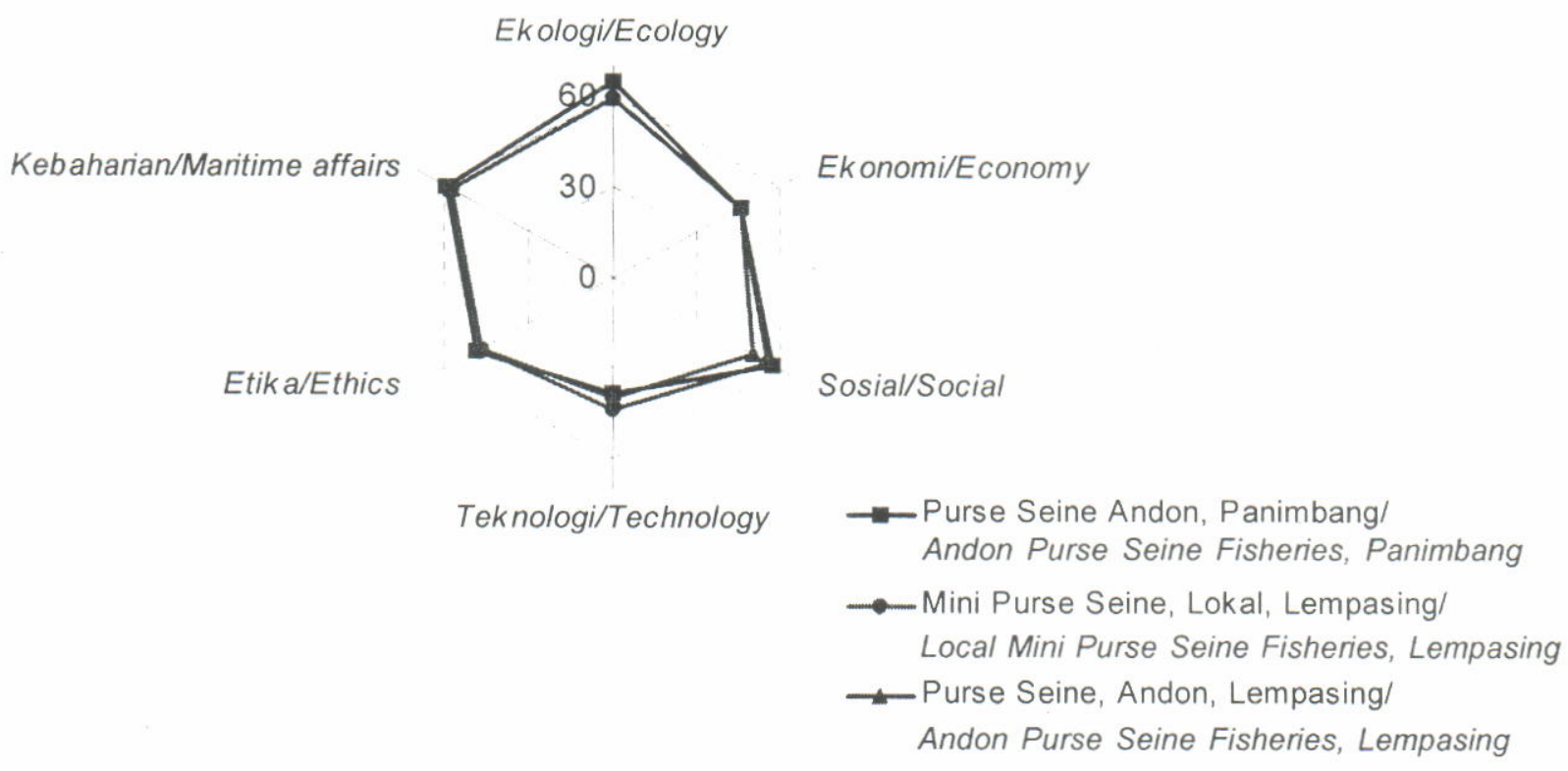

Gambar 1. Diagram radar status perikanan purse seine nelayan andon dan nelayan lokal di Selat Sunda, 2003.

Figure 1. Radar diagram of the status of andon and local purse seine fisheries in Sunda Strait, 2003.

\section{Dimensi Teknologi}

Dibanding dengan nelayan andon, kinerja mini purse seine ${ }^{1)}$ yang dioperasikan oleh nelayan lokal di Lempasing, Bandar Lampung, lebih tinggi dari skala yang ditunjukkan oleh purse seine andon, baik yang berbasis di Panimbang maupun Lempasing. Dari 10 atribut yang dikaji, hasil skoring yang didasarkan atas data yang berhasil dihimpun (Lampiran 1) mengindikasikan bahwa keunggulan kinerja dimensi teknologi perikanan lokal tersebut di atas terkait dengan alat penarik ikan (fish aggregating devicine, FAD), ukuran kapal dan durasi tangkap, dan efektivitas tangkap. Hal ini ditunjang oleh hasil analisis leverage yang menunjukkan bahwa dalam pembandingan nelayan andon dan lokal, atribut-atribut gear, yaitu gear selectivity, $F A D$, dan on-board handling, merupakan atribut yang paling sensitif di antara atribut yang lain.

Dengan kemampuan permodalan yang rendah, nelayan mini purse seine lokal terbatasi oleh peluang pengembangan armada, ukuran kapal, efektivitas, dan jangkauan wilayah penangkapannya. Panjang ratarata perahu mini purse seine ini tidak melebihi 10 meter, jauh lebih kecil dibanding dengan kapal purse seine yang dioperasikan oleh nelayan andon. Ditambah dengan alat bantu (fish aggregating device, FAD) yang hanya berupa lampu tekan (petromaks) berjumlah kurang lebih 10 buah, efektivitas usaha nelayan mini purse seine lokal ini sangat tidak sepadan dibanding dengan efektivitas nelayan andon, yang juga mempergunakan lampu berkekuatan hingga ratusan ribu watt. Rendahnya efektivitas, daya jelajah, dan kesederhanaan alat bantu yang digunakan secara umum sangat menekan kemampuan nelayan mini purse seine lokal untuk melakukan kegiatan eksploitasi sumberdaya di Selat Sunda.

Dari sudut pandang keberlanjutan perikanan, keterbatasan kemampuan yang mencirikan perikanan nelayan lokal tersebut justru bersifat positif. Analisis Rapfish menempatkan pengoperasian armada yang eksploitatif sebagai suatu aktivitas yang mempunyai potensi perusakan atau dampak negatif terhadap sumberdaya. Penggunaan lampu, dan jenis FAD lain, secara berlebihan sebagaimana penggunaan ratusan ribu watt lampu penarik ikan pada perikanan purse seine andon jelas termasuk bentuk tindakan yang sangat eksploitatif. Aplikasi cahaya dengan kekuatan yang sangat besar pada penangkapan ikan akan memaksakan konsentrasi ikan pada satu lokasi sehingga besar kemungkinan bahwa secara agregat ${ }^{2)}$

Pada Gambar 1 dilukiskan dengan simbol bulat

2) Dalam konteks perikanan yang lebih besar (memandang perikanan Selat Sunda secara utuh), kegiatan over-exploitatif di satu lokasi ini akan menyebabkan inefisiensi besar di bagian perairan Sunda yang lain. 
akan terjadi tingkat penangkapan sub-optimal: penangkapan melebihi batas dimana sumberdaya mampu menanggung.

Hal yang lebih memperburuk keadaan adalah bahwa kondisi besarnya efektivitas tersebut di atas berada dalam kecenderungan yang meningkat. Ukuran kapal maupun FAD yang dioperasikan meningkat dari waktu ke waktu. Berdasarkan catatan yang dihimpun di tempat-tempat pendaratan kapal purse seine, panjang rata-rata saat ini meningkat lebih kurang 10-15\% dibanding lima tahun sebelumnya. Sementara itu, kapasitas lampu yang digunakan meningkat lebih dari 200\%. Sebagai ilustrasi, pada waktu-waktu sebelumnya daya yang dialokasikan untuk menopang pengoperasian lampu penarik ikan hanya merupakan alokasi terbatas dari tenaga mesin penggerak kapal; saat ini, sebagian kapal bahkan menggunakan sebuah mesin penggerak kendaraan darat (truk) yang hanya untuk menopang kebutuhan listrik untuk lampu penarik ikan.

Kecenderungan peningkatan efektivitas tangkap juga terjadi pada perikanan lokal, yang mengoperasikan alat mini purse seine. Namun demikian, dalam konteks pembandingan dengan perikanan andon peningkatan tersebut terjadi pada tingkat yang tidak signifikan. Di Lempasing, hasil wawancara dengan nelayan menunjukkan adanya beberapa peningkatan dimaksud. Misalnya, beberapa tahun sebelumnya hanya ada sekitar 3-5 lampu tekan penarik ikan dalam setiap satu perahu, saat ini nelayan menggunakan jumlah 2 s/d 3 kali lipat dibanding waktu-waktu sebelumnya.

Lepas dari lebih tinggi atau lebih rendahnya kinerja kelompok perikanan satu dibanding yang lain pada dimensi ini, secara umum hasil analisis menunjukkan bahwa keduanya berada pada kisaran nilai di bawah 50 (berdasarkan skala 0-100). Ini berarti bahwa pada keduanya memerlukan perbaikan yang diarahkan pada peningkatan kinerja dimensi teknologi. Dalam hubungannya dengan perbaikan tersebut, hal-hal yang perlu dijadikan prioritas dapat dilihat pada bagian akhir dari makalah ini, yang perumusannya akan didasarkan pada hasil analisis leverage untuk masingmasing dimensi yang dikaji.

\section{Dimensi Sosial}

Pada dimensi sosial, data skoring (Lampiran 1) menunjukkan bahwa keunggulan perikanan lokal dibanding dengan perikanan andon kemungkinan terkait dengan beberapa perbedaan, di antaranya: konflik antar kelompok nelayan, penyertaan kerabat dalam usaha, dan pengaruh nelayan dalam penerapan kebijakan. Analisis leverage menunjukkan bahwa dalam pembandingan nelayan andon dan lokal, atribut- atribut conflict status, fisher's influence, dan new entrants into the fishery merupakan atribut yang paling sensitif di antara atribut yang lain.

Senada dengan interpretasi yang diberikan pada pembahasan mengenai dimensi teknologi, hasilhasil analisis Rapfish untuk dimensi sosial dalam konteks pembandingan nelayan purse seine andon dan lokal adalah sebagai berikut: Atribut fishing income dan socialization in fishing menunjukkan skor yang cukup tinggi (Lampiran 1) sehingga berpotensi mengangkat kinerja sosial secara keseluruhan. Namun demikian, atribut conflict status dan fisher's influence, yang menunjukkan skala tinggi pada analisis leverage, mempunyai skor yang rendah Dengan demikian, skor rendah atribut yang berpengaruh ini cenderung mengalahkan skor tinggi pada atribut fishing income dan socialization in fishing. Hasil dari interaksi antar atribut dengan skor ratarata yang berbeda tersebut adalah rata-rata nilai dimensi sosial yang tidak terlalu tinggi, sebagaimana ditunjukkan pada Gambar 1

Pada dimensi ini, purse seine lokal unggul karena perikanan ini tidak menimbulkan konflik, sedangkan nelayan andon harus menghadapi resistensi, yang merupakan sumber konflik dengan nelayan lain. Keberadaan nelayan andon saat ini telah menimbulkan masalah sosial dalam perikanan di Selat Sunda. Di Propinsi Banten maupun Lampung, keberadaan kapalkapal purse seine andon telah menyebabkan persaingan tidak seimbang dalam arena penangkapan ikan pelagis kecil di Selat Sunda. Kesulitan yang dialami oleh nelayan lokal tersebut pada gilirannya menciptakan ketimpangan sosial yang kemudian teraktualisasikan ke dalam konflik fisik, sebagaimana kasus pembakaran nelayan andon di Panimbang (Banten) di tahun 2000 dan 2002, atau demonstrasi penentangan pendaratan hasil tangkapan nelayan andon di Lempasing (Lampung) pada periode yang hampir bersamaan. Dampak ekonomis dari keberadaan andon di Banten dapat diindikasikan dengan menghilangnya purse seine (mini) lokal dari kompetisi usaha di kawasan tersebut. Dari sisi ini, keberadaan nelayan andon menyebabkan turunnya ukuran kinerja sosial karena ukuran pemerataan (dalam hal ini adalah antar pengguna sumberdaya) memburuk.

Satu atribut yang mendongkrak kinerja agregat dimensi sosial dari purse seine Panimbang adalah entrants into the fishery (lihat Lampiran 1). Dengan demikian purse seine Panimbang untuk dimensi ini sama dengan nilai yang diperoleh mini purse seine milik nelayan lokal. Meskipun hanya merupakan satusatunya keunggulan yang dimiliki oleh purse seine Panimbang, keunggulan tersebut telah cukup berdampak terhadap nilai yang didapat oleh perikanan 
tersebut karena keunggulan tersebut terjadi pada atribut dengan skala tinggi pada analisis leverage. Observasi lapang menunjukkan bahwa tampak adanya resistensi dari nelayan lokal terhadap perkembangan lebih lanjut dari purse seine andon.

\section{Dimensi Lain}

Untuk dimensi lainnya, perikanan purse seine yang dioperasikan oleh nelayan andon yang berbasis Panimbang, menunjukkan keunggulan, baik dibandingkan dengan perikanan mini purse seine yang dioperasikan oleh nelayan lokal maupun sesama perikanan andon yang berbasis di Lempasing. Dari pengukuran atribut-atribut dimensi ekologi (Lampiran 1), tercatat atribut-atribut discarded by catch dan exploitation status sebagai atribut yang paling berpotensi menyebabkan perbedaan tersebut.

Perbedaan yang terjadi dari sisi discarded by catch dikarenakan pada musim-musim tertentu, di kawasan Selat Sunda, terjadi produksi ikan cekong secara sangat berlimpah. Ikan yang juga dikenal dengan ikan krismon tersebut mempunyai harga yang relatif murah dibanding ikan-ikan tangkapan lainnya di Lampung (Lempasing). Murahnya harga ikan ini tidak sampai menyebabkan nelayan Lampung melakukan pembuangan ikan tersebut ke laut. Sebaliknya, nelayan di Banten (Panimbang) sering merasa perlu membuang kembali hasil tangkapan ikan cekong tersebut karena tidak ekonomis untuk membawa ikan tersebut ke darat. Fenomena ini merupakan sesuatu yang dapat diabaikan di dalam Analisis Rapfish, meskipun tidak dapat dikatakan sebagai hal yang dapat dikategorikan untuk skor tertentu berdasarkan kategori Rapfish. Dengan demikian, skor yang diberikan adalah 0.5 (berdasarkan skala 0-2.0). Dalam hal exploitation status, dengan jangkauan operasi yang terbatas, nelayan mini purse seine lokal merasakan bahwa sumberdaya perikanan yang mereka manfaatkan telah tereksploitasi cukup berat. Sebaliknya, bagi nelayan andon, dengan jangkauan yang lebih luas, masih terdapat peluang yang lebih besar untuk menemukan lokasi penangkapan yang belum terlalu terkuras.

Hasil analisis leverage untuk dimensi yang sama (Dimensi Ekologi) juga mendukung kesimpulan atas hasil analisis ordinansi sebagaimana yang dimaksud di atas. Tercatat tiga (3) atribut mendapatkan skala tinggi, yaitu size of fish caught, range collapse, dan discarded by catch. Kedua atribut pertama menunjukkan angka yang sama rendah pada semua ketiga perikanan dan keduanya dapat menerangkan kemungkinan hasil analisis ordinasi yang memunculkan exploitation status sebagai atribut yang berpotensi menentukan status perikanan dalam dimensi ekologi. Sedangkan atribut discarded bycatch dengan angka rendah, terutama ditunjukkan oleh perikanan purse seine Panimbang, selaras pula dengan kesimpulan atas hasil analisis ordinasi yang menunjuk atribut yang sama (discarded by catch) sebagai atribut yang berpotensi dalam menentukan status perikanan yang dianalisis ini. Dengan demikian, penyusunan kebijakan-kebijakan ke depan perlu memberikan perhatian yang lebih pada kedua atribut tersebut.

Pada dimensi ekonomi, ketiga perikanan menunjukkan kinerja yang sama dengan sama-sama memiliki nilai skala 46 (lihat Tabel 1 dan Gambar 1). Analisis leverage menunjukkan bahwa dalam pembandingan nelayan andon dan lokal, atribut-atribut marketable right, other income, dan sector employment merupakan atribut yang paling sensitif di antara atribut yang lain. Data yang terkumpul dari kegiatan lapang menunjukkan bahwa kecuali untuk perikanan payang di Banten, ketersediaan Mata Pencaharian Alternatif (MPA) merupakan hal yang menonjol terkait dengan dimensi ini. Meskipun sebagian nelayan memiliki beberapa jenis ketrampilan yang memungkinkan untuk mereka bekerja di bidang lain, ketersediaan MPA tidak ada atau dalam jumlah yang sangat terbatas. Karena berdasarkan analisis leverage atribut ini juga termasuk yang berpengaruh, maka perancangan kebijakan dan implementasinya yang bertujuan mengembangkan industri alternatif perikanan (misalnya pengolahan/processing) merupakan hal yang patut diperhatikan ke depannya.

Kebijakan yang diarahkan pada penanganan atribut other income melalui pengembangan industri pengolahan sebagaimana diusulkan di atas, secara simultan dapat pula berdampak positif ganda. Kebijakan ini terkait pula dengan kebijakan yang memperhatikan atribut discarded by catch pada dimensi ekologi. Pengamatan di lapangan menunjukkan kebijakan yang terkait telah mulai dilaksanakan dan dikembangkan di wilayah Kabupaten Lampung Selatan, misalnya industri pengolahan tepung ikan dan penanganan pasca panen rajungan. Peluang untuk mengembangkan industri serupa di wilayah-wilayah lain di kedua propinsi yang berbatasan dengan Selat Sunda tampaknya masih terbuka lebar karena sejauh ini kegiatan pengolahan masih sangat terbatas (Eliza, 2000). Lebih lanjut, dalam hubungannya dengan andon dan lokal, pengembangan pasca panen tersebut juga berpotensi mengurangi peluang terjadinya konflik antar nelayan. Sebagai contoh, apabila nelayan mini purse seine di Lempasing dapat mengolah hasil tangkapannya menjadi produk yang memiliki nilai lebih, dapat diharapkan bahwa resistensi mereka terhadap pendaratan hasil tangkapan purse 
seine andon dapat berkurang karena target dan pangsa pasar keduanya menjadi berbeda.

Pada Dimensi Etika tidak ditemukan suatu kinerja perikanan yang menonjol di antara ketiga perikanan yang dikaji. Hal ini dikarenakan ketiga perikanan tersebut memiliki nilai skala dibawah 50, sebagai akibat dari rendahnya sebagian skor pada atributatribut dalam dimensi ini. Analisis leverage pada kondisi status perikanan yang demikian menunjukkan bahwa dalam konteks pembandingan nelayan andon dan lokal, just management, illegal fishing, dan discards and wastes merupakan atribut-atribut yang paling sensitif di antara atribut lainnya. Untuk itu, perlu kebijakan-kebijakan yang bertujuan mengembangkan industri pengolahan, sebagaimana terkait dengan arahan untuk dimensi lain, serta kebijakan dalam hal penanganan illegal fishing. Penanganan kegiatan destruktif ini dapat diusahakan di antaranya melalui pendataan kapal secara lebih baik. Saat ini, banyak terjadi, baik untuk kapal purse seine besar milik nelayan andon, purse seine mini milik nelayan lokal, ataupun kapal-kapal perikanan lain yang tidak terdata secara baik. Beberapa kapal ikan yang tidak tercatat dalam penangkapan di wilayah Selat Sunda tetapi melakukan operasi penangkapan di wilayah tersebut, beberapa kapal tercatat memiliki ukuran tertentu tetapi pada kenyataannya memiliki ukuran yang lebih besar.

Pada Dimensi Kebaharian tidak tercatat adanya perbedaan di antara ketiga perikanan yang dikaji. Hal ini dikarenakan kesamaan subyek dari atribut yang diuji, dalam hal ini skor-skor untuk atribut kebaharian lebih banyak tergantung pada hal-hal yang terkait dengan pemerintah dan nelayan dimana basis perikanan tersebut dikaji, tidak pada nelayan atau pengusaha yang bersangkutan. Analisis leverage terhadap dimensi ini menunjukkan bahwa atribut appreciation to marine esthetics merupakan atribut yang paling sensitif di antara atribut yang lain. Sementara itu, data pada Lampiran 1 menunjukkan tingginya ratarata skor untuk berbagai atribut, terkecuali appreciation to marine esthetics. Dengan demikian, perlu kebijakan yang di satu sisi secara konsisten dapat terus mempertahankan skor tinggi pada sebagian atribut dan di sisi lain dapat memperbaiki kondisi perikanan yang diwakili oleh atribut appreciation to marine esthetics, sebagai atribut dengan skala tinggi menurut analisis leverage. Pendekatan kampanye melalui berbagai cara merupakan strategi yang teridentifikasi dalam penelitian ini. Pengkajian yang lebih mendalam perlu dilakukan mengingat bahwa hal ini terkait dengan banyak aspek, termasuk aspek sosekbud.

\section{KESIMPULAN DAN SARAN}

Bagi Propinsi Lampung maupun Propinsi Banten terdapat persamaan pada potensi dan permasalahan dalam hal pengelolaan perikanan tangkap di Selat Sunda. Dari jumlah produksi perikanan tangkap yang didaratkan, Selat Sunda merupakan aset ekonomi yang penting bagi kedua propinsi. Permasalahan serupa yang dihadapi di kedua propinsi terutama bersumber dan terkait dengan konflik potensial dan aktual antara nelayan andon dengan nelayan lokal.

Status perikanan nelayan andon dan nelayan lokal di Selat Sunda berdasarkan hasil analisis Rapfish menunjukkan bahwa masih terdapat peluang untuk mengusahakan kelestarian ekologis, dikarenakan kinerja dari alat tangkap yang dioperasikan bersifat 'sedang' menurut standar Rapfish. Namun demikian, perlu diperhatikan beberapa arahan kebijakan yang dapat menunjang keberhasilan optimalisasi nilai ekonomi total perikanan tangkap tersebut, yaitu: (1) Pengembangan teknologi penangkapan yang ramah lingkungan; (2) Pengembangan program pembiayaan kegiatan penangkapan skala usaha menengah, terutama untuk masyarakat nelayan lokal; (3) Pengembangan Mata Pencaharian Alternatif (MPA), baik di sektor perikanan maupun di sektor non perikanan; (4) Penanganan illegal fishing, termasuk diantaranya sinkronisasi prosedur perijinan kegiatan penangkapan antar instansi, pusat hingga daerah dan pemberdayaan masyarakat dalam penanganan illegal fishing; dan (5) Program bersifat kampanye yang bertujuan untuk menumbuh kembangkan kecintaan dan kepedulian masyarakat terhadap sumberdaya kelautan dan perikanan.

\section{DAFTAR PUSTAKA}

Daniel, M. 2002. Metode Penelitian Sosial Ekonomi Dilengkapi Beberapa Alat Analisa dan Penuntun Penggunaan. Penerbit Bumi Aksara. Jakarta. 166 pp.

Eliza, L. 2000. Industri Pengolahan Perikanan Sebagai Peluang Investasi. http://www.dkp-banten.go.id/ IrLimEliza01.htm

Nijkamp, P. 1980. Environmental Policy Analysis: Operational Methods and Models. John Wiley and Sons. New York

Pitcher, T.J. and Preikshot., D. 2001. Rapfish: A Rapid Appraisal Technique to Evaluate the Sustainability Status of Fisheries. Fisheries Research 49 (3):255270. 
Lampiran 1. Skoring analisis rapfish perikanan andon dan perikanan lokal di Selat Sunda, 2003

Appendix 1. Scoring of rapfish analysis of andon and local fisheries in Sunda Strait, 2003

\begin{tabular}{|c|c|c|c|}
\hline \multirow[b]{2}{*}{$\begin{array}{c}\text { Dimensi - Atribut/ } \\
\text { Dimensions - Attributes }\end{array}$} & \multicolumn{3}{|c|}{ Perikanan yang dianalisis/Analysed fisheries } \\
\hline & $\begin{array}{c}\text { Purse seine andon } \\
\text { Panimbang/Andon } \\
\text { purse seine fisheries } \\
\text { Panimbang }\end{array}$ & $\begin{array}{l}\text { Purse seine lokal } \\
\text { Lempasing/Local } \\
\text { purse seine fisheries } \\
\text { Lempasing }\end{array}$ & $\begin{array}{c}\text { Purse seine andon } \\
\text { Lempasing/Andon } \\
\text { purse seine fisheries } \\
\text { Lempasing }\end{array}$ \\
\hline \multicolumn{4}{|l|}{ ECOLOGICAL } \\
\hline Exploitation status & 0.5 & 0.5 & 1 \\
\hline Recruitment of variability & 1 & 1 & 1 \\
\hline Change in trophic level & 1 & 1 & 1 \\
\hline Migratory range & 1 & 1 & 1 \\
\hline Range collapse & 0 & 1 & 1 \\
\hline Size of fish caught & 1 & 1 & 1 \\
\hline Catch before maturity & 0 & 0 & 0.5 \\
\hline Discarded by catch & 0 & 0 & 0 \\
\hline Species caught & 0 & 1 & 0 \\
\hline Primary production & 3 & 3 & 3 \\
\hline \multicolumn{4}{|l|}{ ECONOMIC } \\
\hline Profitability & 0.5 & 0.5 & 0.5 \\
\hline Fisheries in GDP & 0.5 & 0.5 & 0.5 \\
\hline Average wage & 3 & 3 & 3 \\
\hline Limited entry & 1 & 1 & 1 \\
\hline Mark etable right & 2 & 2 & 2 \\
\hline Other income & 3 & 3 & 3 \\
\hline Sector employment & 2 & 2 & 2 \\
\hline Ownership transfer & 1 & 1 & 1 \\
\hline Market & 1 & 1 & 1 \\
\hline Subsidy & 1 & 1 & 1 \\
\hline \multicolumn{4}{|l|}{ SOCIAL } \\
\hline Socialization of fishing & 1.5 & 1.5 & 1.5 \\
\hline New Entrants into the fishery & 1 & 2 & 2 \\
\hline Fishing sector & 1 & 2 & 2 \\
\hline Environmental knowledge & 1.5 & 1.5 & 0.5 \\
\hline Education level & 1 & 1 & 1 \\
\hline Conflict status & 0 & 2 & 0 \\
\hline Fisher influence & 1 & 1 & 1 \\
\hline Fishing income & 2 & 2 & 2 \\
\hline Kin participation & 0 & 0 & 0 \\
\hline
\end{tabular}


Lampiran 1. Skoring analisis rapfish perikanan andon dan perikanan lokal di Selat Sunda, 2003 (lanjutan) Appendix 1. Scoring of rapfish analysis of andon and local fisheries in Sunda Strait, 2003 (continued)

\begin{tabular}{|c|c|c|c|}
\hline \multirow[b]{2}{*}{$\begin{array}{c}\text { Dimensi - Atribut/ } \\
\text { Dimensions - Attributes }\end{array}$} & \multicolumn{3}{|c|}{ Perikanan yang dianalisis/Analysed fisheries } \\
\hline & $\begin{array}{c}\text { Purse seine andon } \\
\text { Panimbang/Andon } \\
\text { purse seine fisheries } \\
\text { Panimbang }\end{array}$ & $\begin{array}{l}\text { Purse seine lokal } \\
\text { Lempasing/Local } \\
\text { purse seine } \\
\text { fisheries Lempasing }\end{array}$ & $\begin{array}{c}\text { Purse seine andon } \\
\text { Lempasing/Andon } \\
\text { purse seine fisheries } \\
\text { Lempasing }\end{array}$ \\
\hline \multicolumn{4}{|l|}{ TECHNOLOGICAL } \\
\hline Trip length & 4 & 0 & 2 \\
\hline Landing sites & 2 & 2 & 2 \\
\hline Pre-sale processing & 1 & 1 & 1 \\
\hline On-Board handling & 1 & 1 & 1 \\
\hline Gear & 1 & 1 & 1 \\
\hline Selective gear & 1 & 1 & 1 \\
\hline FADS & 1 & 0.75 & 1 \\
\hline Vessel size & 2 & 2 & 2 \\
\hline Catching power & 2.5 & 2 & 3 \\
\hline Gear side effects & 0 & 0 & 0 \\
\hline \multicolumn{4}{|l|}{ ETHICAL } \\
\hline Adjacency and reliance & 1.5 & 3 & 1.5 \\
\hline Altematives & 0 & 0 & 0 \\
\hline Equity in entry & 1 & 0.5 & 1 \\
\hline Just management & 0 & 0.5 & 0 \\
\hline Influences in ethical formation & 2 & 2 & 2 \\
\hline Mitigation of habitat destruction & 1 & 1 & 1 \\
\hline Mitigation of ecosystem depletion & 1 & 1 & 1 \\
\hline Illegal fishing & 0 & 0 & 0 \\
\hline Discards and wastes & 0 & 0 & 0 \\
\hline Conflict of regulation & 0 & 0.5 & 0.5 \\
\hline Law enforcement & 0 & 0 & 0 \\
\hline \multicolumn{4}{|l|}{ MARITIME } \\
\hline Maritime appreciation & 1 & 0 & 0 \\
\hline People participation & 1 & 1 & 1 \\
\hline Appreciation to marine esthetic & 0.5 & 0.5 & 0.5 \\
\hline Satisfaction to work of oceanic & 1.5 & 1.5 & 1.5 \\
\hline Appreciation to fishery product & 1 & 1 & 1 \\
\hline Management regulation & 1 & 1 & 1 \\
\hline
\end{tabular}


